\title{
ISU DAN TREN PENELITIAN EKSPERIMEN \\ PADA PENDIDIKAN BIOLOGI
}

\author{
Djohar Maknun
}

\section{Pendahuluan}

Perkembangan ilmu pengetahuan tidak serta merta. Ilmu pengetahuan sangat berguna untuk keberlangsungan hidup manusia. Penerapan ilmu pengetahuan pada kehidupan manusia memerlukan proses. Salah satu prosesnya adalah melalui penelitian. Pengembangan ilmu pengetahuan sangat diperlukan demi keberlangsungan hidup manusia. Hal ini seperti yang disampaikan UNESCO (2009) bahwa "scientific development in recent decades has, and will continue to have, a significant influence on topics that have great importance for humanity, quality of life, the sustainable development of the planet, and peaceful coexistence amongst peoples".

Di antara banyak ilmu pengetahuan, salah satunya adalah pendidikan biologi. Perkembangan penelitian di bidang pendidikan biologi juga terus mengalami perkembangan. Demi mengetahui isu dan tren penelitian pada bidang pendidikan biologi, maka perlu dilakukan kajian. Kajian ini diharapkan dapat memetakan berbagai pengetahuan yang sudah dan akan dikembangkan. Jika memungkinkan, kajian ini juga dapat menjadi rujukan dalam penentuan permasalahan pendidikan biologi yang perlu dikembangkan.

\section{Pembahasan}

\section{a. Penelitian}

Penelitian merupakan aktivitas mengamati, menganalisis, serta memberi simpulan dari berbagai fakta yang ada. Hal ini sejalan dengan pendapat Muhammad Ali (dalam Hadi dan Haryono, 2005) yang menyatakan bahwa penelitian merupakan cara untuk memahami suatu masalah melalui pengumpulan 
bukti serta analisis secara detil dan hati-hati sehingga ditemukan jawaban dari masalah tersebut.

Dalam penelitian terdapat suatu rancangan. Creswell (2012) berpendapat, 'rancangan penelitian merupakan rencana dan prosedur penelitian yang meliputi: dari asumsi-asumsi luas hingga metode-metode rinci dalam pengumpulan dan analisis data" . Creswell (2012) membagi rancangan penelitian menjadi tiga, yakni kualitatif, kuantitatif, dan campuran. Sementara Sugiyono (2012) membagi menjadi dua besar, yakni berdasarkan tujuan penelitian dan tingkat kealamiahan tempat penelitian. Hal ini nampak seperti gambar berikut.

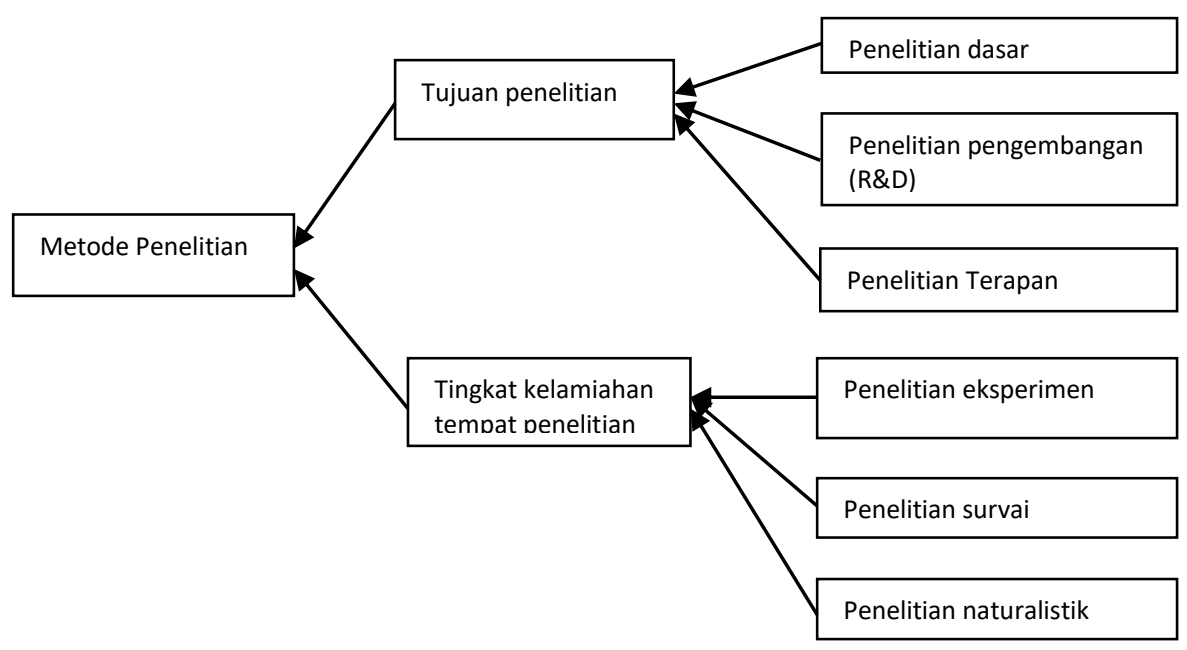

\section{Gambar 1. Macam Metode Penelitian (Sugiyono, 2012)}

Demi memanfaatkan waktu, pada kesempatan kali ini hanya akan dibahas metode penelitian eksperimen. Seperti telah diketahui bersama bahwa pada penelitian eksperimen terdapat perlakuan atau treatment. Penelitian ini memisahkan antara kelompok kontrol dan kelompok eksperimen. Bentuk disain penelitian eksperimen dapat dilihat pada gambar berikut. 


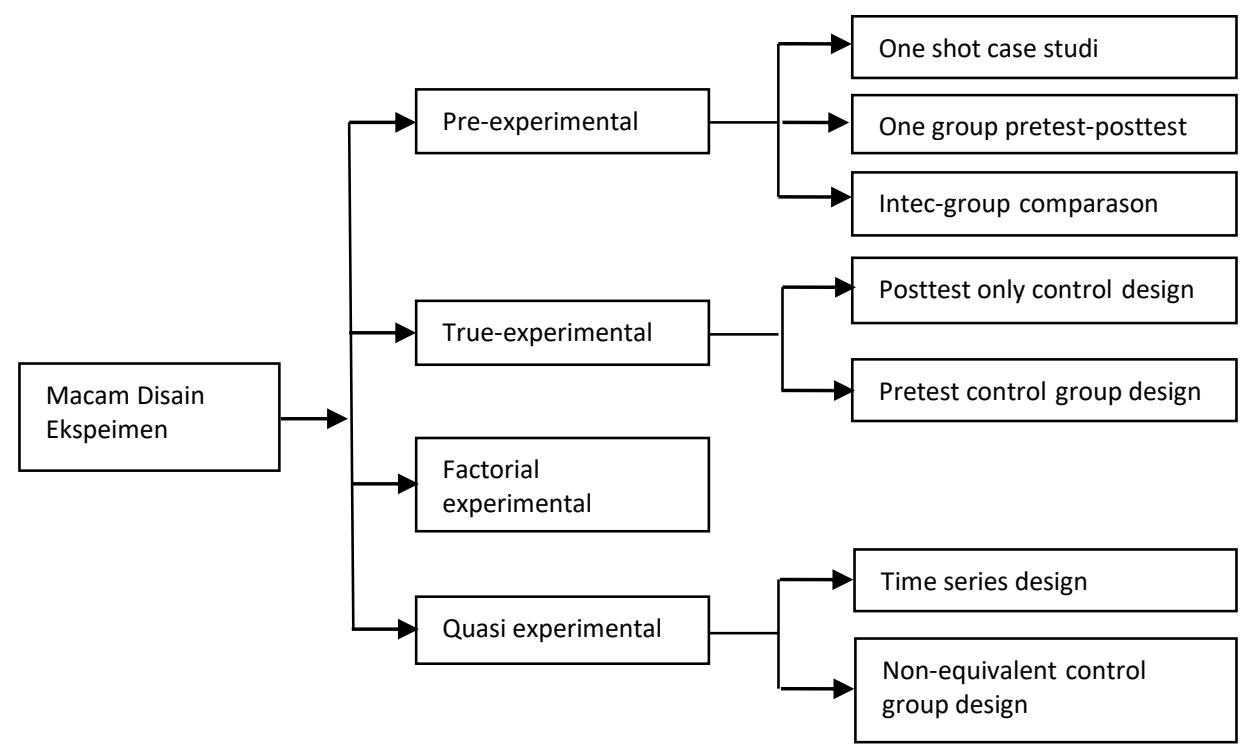

Gambar 2. Macam-macam Metode Eksperimen (Sugiyono, 2012)

\section{b. Pendidikan Biologi}

Biologi merupakan bagian dari sains. Biologi mempelajari segala hal yang terkait dengan kehidupan, baik manusia, hewan, maupun tumbuh-tumbuhan. Pembelajaran sains tidak hanya berupa penyampaian gagasan, tetapi juga pada penerapannya. Hal inilah yang kemudian menggeser pembelajaran sains yang berorientasi 'telling science' menjadi 'doing science'. Para lulusan diharapkan tidak hanya menguasai satu ranah kemampuan, tetapi memiliki ketiganya, yakni kognitif, afektif, dan psikomotor. Adapun ranah afektif yang diharapkan adalah pada bersikap ilmiah atau yang biasa disebut dengan 'scientific attitude'.

Dalam pendidikan biologi hendaknya disampaikan permasalahan yang bermanfaat bagi kehidupan manusia. Permasalahan itu diupayakan terselesaikan melalui berbagai penelitian. Hasil penelitian diharapkan dapat menjawab persoalan-persoalan yang ada. Walaupun permasalahan yang dihadapi manusia tidak dapat diselesaikan melalui satu bidang, tetapi setidaknya dapat diupayakan 
penyelesaiannya dari bidang biologi. Oleh karena itu, peran pendidikan biologi sangat penting.

\section{c. Penelitian Pendidikan Biologi Kekinian}

Keberadaan Jurusan atau Program Studi Pendidikan Biologi pun memiliki peran dalam menjawab permasalahan yang ada. Selain itu, pendidikan Biologi juga berperan dalam menyebarluaskan hasil penelitian tersebut. Oleh karena itu, permasalahan yang diangkat dalam penelitian di Jurusan atau Program Studi Biologi seyogyanya mengikuti perkembangan dan kebutuhan masyarakat. Hasil penelitian Widodo (1997) menunjukkan bahwa penelitian mahasiswa UPI: a) sudah searah dengan penelitian sains internasional, walaupun agak terlambat; b) sebaran konsep yang diteliti, kurang merata; c) populasi mayoritas berjenjang SMA; dan d) metode yang digunakan eksperimen, deskriptif, korelasional, serta studi pustaka.

Lebih dari setengah penelitian menggunakan metode eksperimen (Tabel 1). Metode penelitian yang juga banyak digunakan adalah deskriptif dan korelasional. Pada beberapa tahun terakhir muncul metode penelitian tindakan.

Tabel 1. Metode penelitian yang dilakukan

\begin{tabular}{|c|l|c|}
\hline No & \multicolumn{1}{|c|}{ Metode } & Total \\
\hline 1 & Eksperimen & 313 \\
\hline 2 & Deskriptif & 193 \\
\hline 3 & Penelitian tindakan & 15 \\
\hline 4 & Korelasional & 54 \\
\hline
\end{tabular}

Rahayu (2012) memberi gambaran tentang perkembangan pembelajaran sains di Amerika. Pada tahun 50-an, penguasaan konsep-konsep sains dasar dan proses sains sebagai ketrampilan individu. Pada tahun 80-an, pengubahan orientasi sistem pembelajaran di sekolah. Jika awalnya sistemnya pasif menjadi proses yang lebih aktif serta mengaitkan pembelajaran konsep dengan aplikasinya dalam kehidupan sehari-hari. Pada tahun 90-an, penekanan terhadap pandangan konstruktivistik dalam belajar. 
DeHaan (2011) menyatakan bahawa selama ini pendidikan biologi lebih berorientasi pada "primarily on efforts to improve teaching in high school and introductory college biology courses". Artinya, pembelajaran lebih pada tataran konsep atau berupa pengantar. Pembelajaran biologi belum sampai pada aras penerapan. Hal inilah yang kemudian menyebabkan para lulusan juga belum dapat sampai pada penemuan-penemuan baru. Selama ini, penelitian yang dilakukan cenderung pada pengembangan.

Demikian pun yang terjadi di Universitas Pendidikan Indonesia (UPI). Penelitian yang selama ini dilakukan lebih banyak pada penelitian di dalam kelas, yakni tentang pembelajaran. Hal ini dapat diketahui dari 333 skripsi, 239 meneliti pembelajaran di SMA dan 92 di SMP, sedangkan di SD dan SMK tidak ada, serta 2 meneliti pembelajaran di universitas. Hal ini menunjukkan bahwa penelitian pembelajaran di kelas masih dominan. Adapun konsep biologi yang paling sering dibahas, antara lain: 96 tentang pencemaran, 56 tentang ekologi, 41 tentang sistem reproduksi, dan 39 tentang ekosistem (Widodo, 2009). Lebih lengkap konsep yang diteliti dapat dilihat pada Tabel 2.

Tabel 2. Konsep-konsep yang diteliti

\begin{tabular}{|c|l|c|}
\hline No & \multicolumn{1}{|c|}{ Konsep Biologi } & Total \\
\hline 1 & Pencemaran & 96 \\
\hline 2 & Ekologi & 56 \\
\hline 3 & Sistem reproduksi & 41 \\
\hline 4 & Ekosistem & 39 \\
\hline 5 & Alat indera & 32 \\
\hline 6 & Keanekaragaman hayati & 24 \\
\hline 7 & Sistem pernapasan & 23 \\
\hline 8 & Sistem eksresi hewan dan tumbuhan & 21 \\
\hline 9 & Sistem saraf & 18 \\
\hline 10 & Sistem transportasi hewan \& manusia & 16 \\
\hline 11 & Sistem reproduksi tumbuhan & 16 \\
\hline 12 & Bioteknologi & 16 \\
\hline 13 & Sistem transportasi tumbuhan & 15 \\
\hline 14 & Tumbuhan & 13 \\
\hline 15 & Pemencaran tumbuhan & 11 \\
\hline 16 & Makanan & 10 \\
\hline 17 & Genetika & 9 \\
\hline 18 & Pertumbuhan dan perkembangan & 8 \\
\hline 19 & Invertebarata & 7 \\
\hline
\end{tabular}




\begin{tabular}{|l|l|l|}
\hline 20 & Arthtropoda & 6 \\
\hline 21 & Biologi molekuler & 6 \\
\hline 22 & Metabolisme & 5 \\
\hline 23 & Gerak pada hewan & 5 \\
\hline 24 & Vertebrata & 5 \\
\hline 25 & Lumut & 4 \\
\hline 26 & Virus & 4 \\
\hline 27 & Gerak pada tumbuhan & 4 \\
\hline 28 & Organisasi kehidupan & 4 \\
\hline 29 & Jamur & 3 \\
\hline 30 & Vermes & 3 \\
\hline 31 & Makhluk hidup & 2 \\
\hline 32 & Sistem hormone & 2 \\
\hline 33 & Mutasi & 2 \\
\hline 34 & Kependudukan & 2 \\
\hline 35 & Tumbuhan biji & 2 \\
\hline 36 & Sistem pertahanan tubuh & 2 \\
\hline 37 & Protista & 2 \\
\hline 38 & Reproduksi sel & 2 \\
\hline 39 & Crustacea & 1 \\
\hline 40 & Insecta & 1 \\
\hline 41 & Sistem pengeluaran tumbuhan & 1 \\
\hline 42 & Sistem pencernaa & 1 \\
\hline 43 & Klasifikasi tumbuhan & 1 \\
\hline 44 & Ganggang & 1 \\
\hline 45 & Paku-pakuan & 1 \\
\hline 46 & Evolusi & 1 \\
\hline 47 & Monera & 1 \\
\hline 48 & Biogeografi & 1 \\
\hline 49 & Coelenterata & 1 \\
\hline 50 & Porifera & 1 \\
\hline 51 & Echinodermata & 1 \\
\hline 52 & Sistem rangka & 1 \\
\hline 53 & Biogeokimia & 1 \\
\hline 54 & Sistem transportasi sel & 1 \\
\hline 55 & Fisiologi & 1 \\
\hline 56 & Organisasi sel & 1 \\
\hline 57 & Kinerja ilmiah & \\
\hline 58 & Hewan & 1 \\
\hline 59 & Respirasi sel & 1 \\
\hline 60 & Klasifikasi hewan & 1 \\
\hline & & 2 \\
\hline
\end{tabular}

Penelitian pada umumnya dilakukan pada semeser genap akibatnya konsepkonsep yang ada pada semester gasal sangat jarang diteliti. Secara akademik hal ini kurang baik sebab ada ketidakseimbangan dalam konsep yang dikaji. Tematema penelitian yang diteliti terdapat pada Tabel 3. 
Tabel 3 Tema-tema yang dijadikan penelitian

\begin{tabular}{|c|l|c|}
\hline No & \multicolumn{1}{|c|}{ Tema 1 (variabel bebas) } & Total \\
\hline 1 & Model pembelajaran & 138 \\
\hline 2 & Praktikum & 55 \\
\hline 3 & Media & 52 \\
\hline 4 & Pendekatan & 46 \\
\hline 5 & Asesmen & 39 \\
\hline 6 & Metode pembelajaran & 37 \\
\hline 7 & Pertanyaan & 31 \\
\hline 8 & Peta konsep & 15 \\
\hline 9 & Analisis buku teks & 11 \\
\hline 10 & Inkuiri & 11 \\
\hline 11 & Embedded test & 10 \\
\hline 12 & Gender & 9 \\
\hline 13 & Kesulitan belajar & 8 \\
\hline 14 & Pemberian materi & 7 \\
\hline 15 & IMTAQ & 6 \\
\hline 16 & Portofolio & 6 \\
\hline 17 & Analogi & 5 \\
\hline 18 & Field trip & 5 \\
\hline 19 & Tes & 5 \\
\hline 20 & Kunci determinasi & 4 \\
\hline 21 & Pendidikan nilai & 4 \\
\hline 22 & Laporan praktikum & 3 \\
\hline 23 & Penugasan & 3 \\
\hline 24 & Tahapan pemebalajaran & 3 \\
\hline 25 & Karyawisata & 2 \\
\hline 26 & Kurikulum & 2 \\
\hline 27 & Temperamen & 2 \\
\hline 28 & Analisis gambar & 1 \\
\hline 29 & Analisis soal & 1 \\
\hline 30 & Analisis wacana & 1 \\
\hline 31 & Budaya & 1 \\
\hline 32 & Kajian historis & 1 \\
\hline 33 & Lesson study & 1 \\
\hline 34 & Peer teaching & 1 \\
\hline 35 & Pendidikan lingklungan & 1 \\
\hline 36 & Penilaian produk & 1 \\
\hline 37 & Perkembangan kognitif & 1 \\
\hline 38 & Rubrik & 1 \\
\hline 39 & Struktur belajar & 1 \\
\hline 40 & Tutor sebaya & 1 \\
\hline
\end{tabular}

Tema pendidikan yang kedua pada umumnya merupakan tema yang menjadi akibat dari tema pertama (Tabel 4). Tema kedua ini pada umumnya merupakan hasil belajar siswa (pemahaman, keterampilan proses, kemampuan berpikir, dsb). 
Tabel 4 Tema penelitian sebagai akibat dari tema pertama

\begin{tabular}{|c|l|c|}
\hline No & \multicolumn{1}{|c|}{ Tema 2 } & Total \\
\hline 1 & Pemahaman & 171 \\
\hline 2 & KPS & 107 \\
\hline 3 & Kemampuan berpikir & 56 \\
\hline 4 & Pemecahan masalah & 16 \\
\hline 5 & Interaksi siswa & 15 \\
\hline 6 & Keterampilan psikomotorik & 12 \\
\hline 7 & Kreatifitas & 12 \\
\hline 8 & Sikap & 11 \\
\hline 9 & Keterampilan kooperatif & 11 \\
\hline 10 & Miskonsepsi & 10 \\
\hline 11 & Kinerja siswa & 10 \\
\hline 12 & Keterampilan generic & 9 \\
\hline 13 & Retensi & 9 \\
\hline 14 & Motivasi & 9 \\
\hline 15 & Merumuskan masalah & 9 \\
\hline 16 & Iklim lingkungan emosional & 7 \\
\hline 17 & Kemampuan membaca & 44 \\
\hline 18 & Persepsi siswa & 3 \\
\hline 19 & Life skill & 3 \\
\hline 20 & Keterikatan dan berbagi & 2 \\
\hline 21 & Minat & 2 \\
\hline 22 & Keterampilan elaborasi & 2 \\
\hline 23 & Eneterpreneurship & 1 \\
\hline 24 & Literasi & 1 \\
\hline 25 & Kepribadian & 1 \\
\hline 26 & Kesiapan siswa & 1 \\
\hline 27 & Kompetensi & 1 \\
\hline 28 & Aktivitas & 1 \\
\hline 29 & Metakognisi & 1 \\
\hline 30 & Gaya belajar & \\
\hline & & 1 \\
\hline
\end{tabular}

Hal ini tidak jauh berbeda dengan kecenderungan penelitian yang dilakukan di Universitas Riau. Berdasarkan penelitian yang dilakukan Firdaus L.N. dan Raja Hussien Arief (2014) diperoleh hasil bahwa dari 623 skripsi, 50,2\% melakukan penelitian di jenjang SMA. Metode yang paling banyak digunakan adalah deskriptif (25\%), survei (23,8\%), PTK (19,4\%), eksperimen $(18,1 \%)$, korelasi $(8,8 \%)$, komparatif $(4,6 \%)$, dan studi pustaka $(0,4 \%)$. Terdapat 57 konsep biologi sebagai variabel bebas yang dominan tentang: Polusi, Vegetasi, Alelopati, Biofertilizer, Fitohormon, Insekta \& Bakteri. Sementara terdapat 40 konsep untuk variabel terikat yang paling dominan adalah tentang Pertumbuhan Vegetatif 
Tanaman. Terdapat 152 aspek pembelajaran biologi sebagai Variabel Bebas yang paling dominan adalah tentang Penguasaan Materi. Sementara untuk Variabel Terikat, 20 aspek pembelajaran yang paling dominan adalah tentang hasil belajar.

Kecenderungan penelitian Universitas Muhammadiyah Surakarta (Nugroho dan Hariyatmi, 2015), yaitu terapan $(53,2 \%)$, pendidikan $(30,8 \%)$, dan murni ( $16,0 \%)$. Pendekatan penelitian yang dipilih mahasiwa adalah kualitatif $(47,4 \%)$, kuantitatif $(28,2 \%)$, serta kombinasi $(24,4 \%)$. Metode penelitian yang dipilih mahasiswa eksperimen (67,9\%), deskriptif (25,6\%), eksplorasi $(3,8 \%)$, serta eksplanatif, R\&D, PTK dan kepustakan masing-masing 0,6\%. Jenjang sekolah yang dijadikan fokus dalam penelitian pendidikan, SMP $(83,3 \%)$, SMA (10,4\%), Perguruan Tinggi (4,2\%), dan lain-lain $(2,1 \%)$.

Kecenderungan penelitian di Universitas Sebelas Maret Surakarta pada tahun 2011 dan 2012 menunjukkan bahwa dari 165 skripsi, 74 di antaranya menggunakan metode eksperimen sedangkan sisanya berupa Penelitian Tindakan Kelas (PTK) (Sudarisman, 2013). Namun demikian, hal ini menunjukkan perubahan karena pada tahun 2011, penelitian eksperimen hanya 3 skripsi. Sisanya merupakan penelitian pada tahun 2012.

\section{d. Penelitian Pendidikan Biologi Mendatang}

Mengingat biologi sebagai bidang kajian yang sangat erat dengan kehidupan maka penelitian yang dilakukan sangat diharapkan terus mengalami perkembangan dan pembaharuan. Kecenderungan penelitian pendidikan biologi mendatang diharapkan untuk memperhatikan dan dikaitkan dengan kearifan lokal (Widodo, 1997). Artinya, penelitian hendaknya mengintegrasikan antara biologi dengan dekhidupan sehari-hari. Terutama berbagai kearifan lokal yang dimiliki di wilayah tempat lulusan berada.

Selain itu, penelitian pendidikan biologi diharapkan dapat menumbuhkan pembentukan karakter. Karekter itu berupa sikap ilmiah, meliputi: sikap ingin tahu (curiosity), sikap untuk mendahulukan bukti (respect for evidence), sikap 
terbuka terhadap gagasan baru (flexibility), sikap kritis (critical reflection), sikap peduli terhadap lingkungan dan makhluk hidup (sensitivity to living things and evironment) (Rustaman, TT). Perlunya perubahan sikap ini juga dikemukakan oleh DeHaan (2011) bahwa "involve qualitative investigations with surveys, interviews and case studies to determine when and how biological scientist began to change attitudes toward Biology Education Research and learned how to become education researchers".

Penelitian pendidikan biologi juga diharapkan berorientasi pada pengajaran dengan mengintegrasikan berbagai nilai, seperti nilai agama, nilai sosial, nilai budaya, nilai ekonomi, nilai intelektual, dan nilai pendidikan. Misalnya mengaitkan beberapa ayat Quran dengan asal usul manusia. Demikian juga dengan mengaitkan beberapa nilai pendidikan pada tema reproduksi.

Oleh karena itu, pendidikan biologi diharapkan memperbaiki beberapa hal (Brewer dan Smith, 2009), antara lain "undergraduate biology education for all students, cultivating biological literacy, student-centered undergraduate biology education, preparing campuses for the challenges ahead, unity of purpose". Halhal tersebut dapat dikembangkan melalui berbagai penelitian. Jika memungkinkan juga dapat dijadikan permasalahan dalam penelitian.

Adapun menurut UNESCO (2006), pendidikan biologi hendaknya memperbaiki dalam pemilihan materi, baik pembelajaran maupun penelitian. Tema-tema yang sebaiknya diangkat, antara lain tentang: living organisms, bakteri, enzymes, food tests (seperti: karbohidrat, lipids, protein), photosynthesis, respiration, tropisms, plants and water. Tema-tema tersebut dapat dikembangkan sebagai bahan penelitian dan juga bahan pembelajaran. Hal ini pun senada dengan Pemerintah Kamboja. Berdasarkan hasil penelitian yang telah dilakukan pemerintah Kamboja yang diterbitkan pada tahun 2013, pendidikan biologi juga perlu melakukan kajian pada materi. Kajian ini diharapkan dapat lebih bermanfaat bagi kehidupan manusia di masa datang. Adapun objek kajian itu, antara lain 
meliputi: plants, diffusion and osmosis, the sense of taste, respiration, sight, the sensory system, the heart.

Menurut Dirks (2011), penelelitian pendidikan biologi hendaknya juga meneliti tentang microbiology, neurobiology, genetics, genomics, cell and molecular biology, ecology, evolution, and physiology. Selain itu, juga perlu mengkaji student learning or performance, student attitudes and beliefs, and concept inventories and validated instruments. Hal ini tentu saja demi kemaslahatan bersama.

Menurut Rustaman (2012), bidang penelitian sains yang penting untuk diteliti yaitu:

1. Literasi sains dan literasi membaca.

Literasi atau literacy merupakan salah satu tuntutan bagi warganegara muda usia agar mereka dapat tetap eksis untuk bersaing bebas pada era globalisasi (Hayat, 2003).

2. Sikap ilmiah dan kemampuan dasar bekerja ilmiah.

Beberapa sikap ilmiah (sikap jujur, terbuka, luwes, tekun, logis, kritis, kreatif) penting dalam pembentukan watak atau karakter anak bangsa melalui budi pekerti pada jenjang sekolah (Karhami, 2000).

3. Pendidikan sains sebagai pengembangan berpikir.

Pentingnya peranan proses berpikir berdasarkan pandangan biologi dan peranannya dalam pendidikan sains (Rustaman, 2002) mengingatkan kita semua akan adanya hubungan yang erat antara proses berpikir dengan aspek afektif melalui sistem limbik. Sistem limbik mempunyai peran sebagai pengendali proses berpikir.

4. Pendidikan sains sebagai bekal hidup.

Pendidikan Kehidupan Keluarga (PKK) atau family life education mendapat porsi khusus dalam pendidikan sains. Melalui PKK atau FLE tersebut seyogyanya calon guru sains memperoleh bekal untuk hidup di 
masyarakat terutama dalam hal mendidik para putra-putrinya dan juga bekal untuk mendidik para siswanya.

Keempat hal tersebut secara optimal kurang berkembang di negara kita karena beberapa hal. Pertama, faktor budaya yang tidak memberikan kesempatan anak-anak mengembangkan potensi belahan otak besar sama kuatnya. Kedua, bekal pengetahuan gizi dan kesehatan kurang mendapat perhatian yang proporsional dalam pendidikan. Ketiga, masih kurang kesadaran para pendidik di rumah dan di sekolah untuk menekankan pengembangan kecerdasan intelektual yang seimbang dengan kecerdasan emosional dan spiritual (Rustaman, 2012).

Review yang dilakukan oleh Jenkin (2001) dalam Widodo (2009) menyatakan bahwa penelitian-penelitian yang dilakukan di Eropa menunjukkan penelitian tentang guru, siswa, buku teks, pedagogi, kurikulum dan asesmen sudah banyak dilakukan. Penelitian pendidikan sains di masa mendatang hendaknya mencakup juga penelitian tentang kebijakan dan prakteknya, penelitian tentang pengajaran, penelitian berpikir, kualitas argumentasi, perdebatan dan memperjelas permasalahan yang dihadapi dunia pendidikan sains.

Review yang dilakukan oleh Duit (2007) dalam Widodo (2009) menunjukkan bahwa penelitian pembelajaran senantiasa banyak dilakukan. Di tahun 1980-an banyak sekali dilakukan penelitian tentang konsepsi dan miskonsepsi siswa tentang suatu konsep. Penelitian-penelitian ini kemudian berlanjut dengan penelitian tentang konstruktivisme dan perubahan konseptual (conceptual change) yang banyak dilakukan pada tahun 1990-an. Lebih lanjut Duit (2007) dalam Widodo (2009) menyatakan bahwa penelitian-penelitian pendidikan sains di masa mendatang memiliki karakteristik sebagai berikut:

a. Interdisipliner. Penelitian dikaji dari beberapa disiplin ilmu.

b. Setting nyata.

c. Mengaitkan aspek isi, pedagogi dan psikologi. Penelitian-penelitian yang terpisah-pisah tidak memberikan hasil yang komprehensif. 
Sebaiknya para pakar meneliti fenomena pendidikan dari bidang yang menjadi kepakarannya.

Duit (2007) dalam Widodo (2009) menganjurkan agar penelitian pendidikan di masa mendatang bisa mengkaji masalah secara lebih komprehensif dari berbagai sisi (Gambar 3).

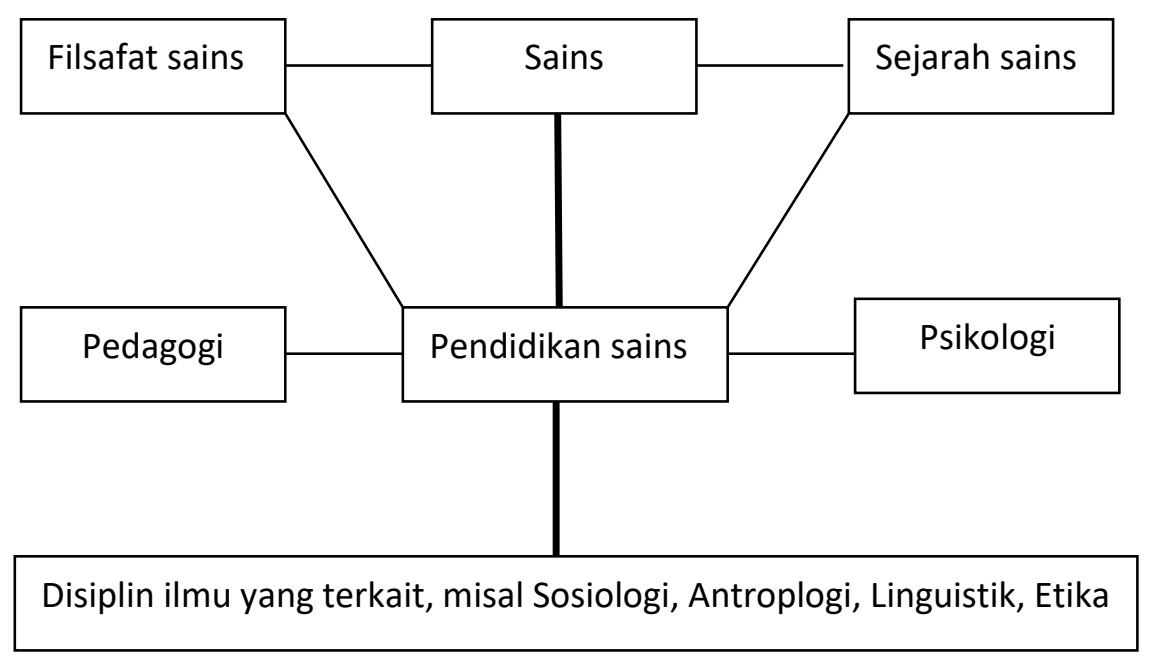

Gambar 3 Disiplin ilmu yang terkait dengan pendidikan sains

Tidaklah berlebihan bila dikatakan kemajuan ilmu memasuki abad XXI dipicu oleh oleh lahirnya sains dan teknologi komputer. Dengan piranti kemajuan sains dan teknologi terutama dalam bidang cognitive science, bio-molecular, information technology dan nano-science. Fenomena ini membawa perubahan dalam bidang penelitian. Pertama, terjadinya konvergensi aktifitas antara saintis yang bergulat dalam ranah teoritis dengan teknolog yang bekerja di ranah praksis. Kedua, yang mengkhususkan diri dalam melakukan R\&D. Ketiga, Tumbuhnya sinergi antara lembaga keilmuan termasuk perguruan tinggi dengan industri untuk memproduksi produk canggih, efisien, efektif, tidak menuntut infrastruktur yang kolosal, dan nilai inovasi yang berbobot pengetahuan (Rosana, 2016). 
Menurut Rosana (2016), penyiapan SDM menghadapi tantangan abad XXI penelitian pendidikan dalam pembelajaran sains dapat menggunakan metode: Penelitian dan Pengembangan (R\&D), mixed methods, deskriptif, survei, lapangan dan kasus. Karena itu, penelitian pendidikan sains hendaknya dilakukan untuk tujuan-tujuan yang jelas seperti tujuan tujuan pembelajaran, pengembangan berpikir, pengembangan karakter bangsa, pembiasaan membaca, bertanya, belajar, dan berpikir produktif, pengembangan potensi manusia Indonesai yang pluralistik, dan kearifan lokal agar sinkron dan berdaya guna bagi bangsa dan masyarakat yang sedang membangun jati dirinya (Rosana, 2016).

Lebih lanjut menurut BSNP (2010) beberapa teknologi masa depan dan akan mengubah paradigma adalah: Nanosains dan teknologi nano, neurosains kognitif, teknologi pencitraan, hologram/holografi dan teknologi informasi. Berbeda dengan abad ke XX dimana sains, teknologi dan seni masih terfragmentasi, mulai abad ini berbagai ilmu mulai mengarah pada konvergensi.

\section{e. Penelitian Pendidikan Biologi Menggunakan Metode Eksperimen}

Begitu banyak penelitian yang telah dilakukan oleh mahasiswa. Begitu banyak pula metode yang digunakan dalam skripsi Prodi Pendidikan Biologi. Di sekian banyak metode, pada kesempatan kali ini akan dikaji skripsi mahasiswa yang menggunakan metode eksperimen dari berbagai perguruan tinggi di Indonesia. Adapun tujuan pengkajian ini adalah untuk mengetahui penelitian eksperimen yang dilakukan mahasiswa Prodi Pendidikan Biologi. Berikut ini beberapa skripsi yang menggunakan penelitian eksperimen.

1. Univeristas Negeri Semarang (Setyaningsih, 2007)

Penelitian ini berjudul "Efektivitas Penerapan Pendekatan Jelajah Alam Sekitar (JAS) dengan Model Pembelajaran Kooperatif Jigsaw pada Submateri Vertebrata di SMP N 3 Ungaran”. Populasi penelitian ini adalah seluruh siswa kelas VII SMP Negeri 3 Ungaran tahun ajaran 2006/2007 yang terdiri dari 
enam kelas dari kelas VII A sampai kelas VII F. Adapun sampelnya adalah semua siswa kelas VII A dan kelas VII B diambil dengan teknik purposive random sampling. Kelas VII A digunakan sebagai kelas eksperimen dan kelas VII B sebagai kelas kontrol. Rancangan penelitian ini menggunakan rancangan randomized control-group only design. Teknik pengumpulan data dilakukan dengan memberikan pre tes dan pos tes.

2. Universitas Sebelas Maret Surakarta (Hastuti dan Setyono, 2009) Penelitian ini berjudul "Variasi Morfologi, Karyotipe dan Pola Pita Protein pada Berbagai Varietas Kamboja Jepang (Adenium Obesum)". Data kualitatif meliputi bentuk dan warna daun dan bunga dari masing-masing varietas. Data morfometri antara varietas dianalisis dengan analisis sidaik ragam (ANAVA). Dilanjutkan dengan uji jarak berganda Duncan (DMRT). Pada taraf 5\% terbukti terdapat beda nyata antarvarietas. Pola pita protein akar, batang, daun serta semua organ dianalisis secara kualitatif menggunakan analisis kelompok hierarkhis Average Linkage (between Groups) dalam program SPSS 10.0.

3. Universitas Negeri Jakarta (Auliaty, 2015)

Penelitian ini berjudul "Pemanfaatan Lapangan Rumput sebagai Sumber Belajar Materi Hubungan Makhluk dan Lingkungan melalui Pembelajaran Investigasi Kelompok dengan Pendekatan Jelajah Alam Sekitar (JAS) di SDN Pulogebang 08 Pagi Jakarta Timur". Adapun populasi penelitian adalah semua siswa kelas IV SDN Pulogebang 08 Pagi Jakarta tahun ajaran 2008/2009. Sampel penelitian ini adalah siswa kelas IV A dan IV B. Data diperoleh melalui nilai pos tes dan pengamatan.

4. Universitas Islam Negeri Sunan Kalijaga Yogyakarta (Infajaro, 2011) Penelitian ini berjudul "Pengaruh Penerapan Model Pembelajaran Kooperatif Tipe Question Student Have terhadap Prestasi Belajar Biologi Materi Virus Kelas X SMA Negeri 1 Banguntapan”. Populasi penelitian ini adalah semua siswa kelas X tahun pelajaran 2010/2011. Pengambilan sampel dilakukan dengan purposive sampling, yakni kelas XA sebagai kelas kontrol dan XD 
sebagai kelas eksperimen. Adapun instrumen yang digunakan untuk mengumpulkan data adalah tes dan angket.

5. Universitas Islam Negeri Syarif Hidayatullah (Puspita, 2011)

Penelitian ini berjudul "Perbedaan Hasil Belajar Biologi antara Siswa yang Diajarkan melalui Pembelajaran Kooperatif Teknik Student Team Achievement Division (STAD) dan Teknik Group Investigation (GI) (Kuasi Eksperimen di SMP YPI, Bintaro). Pengambilan sampel dilakukan dengan menggunakan teknik purposive sampling, yakni 35 siswa untuk kelas eksperimen dan 35 siswa untuk kelas kontrol. Data diperoleh dari hasil tes yang berupa pilihan ganda dan telah diuji reliabilitas dan validitasnya.

6. Universitas Jambi (Kumaladewi, dkk., 2015)

Penelitian ini berjudul "Pengaruh Penggunaan Model Pembelajaran Group Investigasi Bermedia dan Motivasi Belajar Siswa terhadap Pemahaman Konsep Biologi”. Penentuan sampel penelitian dilakukan secara random yang terdiri atas siswa kelas XI IPA SMA Negeri 12 Merangin yang berjumlah 56 orang. Rancangan penelitian terdiri atas dua kelompok, yaitu kelompok eksperimen dan kelompok kontrol. Instrumen yang digunakan yaitu angket dan tes objektif. Data yang diperoleh dianalisis menggunakan ANOVA dua jalur.

\section{Penutup}

Berdasarkan berbagai penelitian eksperimen yang dilakukan mahasiswa Prodi Pendidikan Biologi dapat disimpulkan bahwa penentuan sampel dilakukan dengan teknik random. Adapun disain penelitiannya terdiri atas dua kelompok, yaitu kelompok eksperimen dan kelompok kontrol. Data penelitian diperoleh melalui tes dan observasi.

Di masa mendatang penelitian tentang proses pembelajaran hendaknya mendapatkan lebih banyak perhatian, bukan tentang pembelajarannya saja. Abad XXI dicirikan dengan kemajuan sains dan teknologi dalam bidang cognitive science, bio- 
molecular, information technology dan nano-science. Fenomena ini membawa perubahan dalam bidang penelitian yang berisfat konvergensi, melakukan R\&D dan adanya sinergi antara lembaga keilmuan termasuk perguruan tinggi dengan industri untuk memproduksi produk canggih, efisien, efektif, tidak menuntut infrastruktur yang kolosal, dan nilai inovasi yang berbobot pengetahuan.

\section{Daftar Pustaka}

Auliaty, Y. (2015).’Pemanfaatan Lapangan Rumput sebagai Sumber Belajar Materi Hubungan Makhluk dan Lingkungan melalui Pembelajaran Investigasi Kelompok dengan Pendekatan Jelajah Alam Sekitar (JAS) di SD N Pulogebang 08 Pagi Jakarta Timur”. Universitas Negeri Jakarta. Diunduh dari jurnal.pgsdunj.org/index.php/pgsd/article/view/20 pada 24 September 2016 pukul 07.42 WIB.

Badan Standar Nasional Pendidikan. (2010). Paradigma Pendidikan Nasional Abad XXI.

Brewer, CA dan Smith, D (Ed.). (2009). Vision and Change In Undergraduate Biology Education A Call To Action. American Association For The Advancement Of Science.

Creswell, JW. (2012). Research Design: Pendekatan Kualitatif, Kuantitatif, dan Mixed. Yogyakarta: Pustaka Pelajar.

DeHaan, RL. (2011). Education research in the biological sciences: A nine decade review. Emory University.

Dirks, C. (2011). The Current Status and Future Direction of Biology Education Research National Research Council Commissioned Paper. The Evergreen State College.

Firdaus L.N. dan Arief, R. H. (2014). Trend 25 Tahun (1988-2012) Penelitian Tugas Akhir Mahasiswa Pendidikan Biologi FKIP Universitas Riau. Jurnal Biogenesis, Vol. 10, Nomor 2, Februari 2014.

Hadi, A dan Haryono. (2005). Metodologi Penelitian Pendidikan. Bandung: CV Pustaka Setia.

Hastuti, D, Suranto dan Setyono P. (2009). Variasi Morfologi, Karyotipe dan Pola Pita Protein pada Berbagai Varietas Kamboja Jepang (Adenium obesum). Universitas Sebelas Maret Surakarta: Nusantara Bioscience 1:78-83. 
Hayat, B. (2003). Kemampuan Dasar Hidup: Prestasi Literasi Membaca, Matematika dan Sains Anak Indonesia Usia 15 Tahun di Dunia Internasional. Jakarta: Pusat Penilaian Pendidikan.

Infajaro, L. (2011). "Pengaruh Penerapan Model Pembelajaran Kooperatif Tipe Question Student Have terhadap Prestasi Belajar Biologi Materi Virus Kelas X SMA N 1 Banguntapan”. Skripsi. Universitas Negeri Islam Sunan Kalijaga, Yogyakarta.

Karhami, S.K.A. (2000). Sikap Ilmiah sebagai Wahana Pengembangan Unsur Budi Pekerti (kajian melalui sudut pandang pengajaran IPA). Jurnal Pendidikan dan Kebudayaan 027. November 2000. [on line]. Tersedia: http://www.depdiknas.go.id/jurnal/27/sikap_ilmiah_sebagai_wahana_peng.ht $\mathrm{m}$.

Kumaladewi, R.P.J., Asrial dan Hariyadi, B. (2015). "Pengaruh Penggunaan Model Pmbelajarn Group Investigasi Bermedia dan Motivasi Belajar Siswa terhadap Pemahaman Konsep Biologi”. Edu-Sains, Vol4, No.1, Januari 2015. Diunduh dari online journal.unj.ac.id/index.php/edusains/article/download/ pada 24 September 2016 pukul 08.05 WIB.

Nugroho, RT, Hariyatmi. (2015). Kecenderungan Mahasiswa Pendidikan Biologi Fkip Ums Dalam Melaksanakan Penelitian Skripsi Tahun 2015. Artikel skripsi.

Puspita, D.I. (2011). "Perbedaan Hasil Belajar Biologi antara Siswa yang Diajarkan melalui Pembelajaran Kooperatif Teknik Student Team Achievement Division (STAD) dan Teknik Group Investigation (GI)(Kuasi Eksperimen di SMP YPI, Bintaro). Skripsi. Universitas Islam Negeri Syarif Hidayatullah, Jakarta.

Rahayu, S. (2012). Penelitian Pendidikan Kimia: Trend Global. Prosiding Seminar Nasional Kimia Unesa 2012 - ISBN : 978-979-028-550-7 di Surabaya, 25 Februari 2012.

Rosana, D. (2016). Analisis Tren Penelitian Pendidikan Sains. Prosiding Seminar Nasional Pendidikan Guru SD dan Bimbingan Konseling Fakultas Keguruan dan Ilmu Pendidikan Universitas Ahmad Dahlan 2016 - ISBN : 976-60270296-8-2 di Yogyakarta, 20 Maret 2016.

Rustaman, N.Y. (2002). Pandangan Biologi tentang Proses Berpikir dan Implikasinya dalam Pendidikan Sains. Pidato Pengukuhan Guru Besar pada Fakultas Matematika dan Ilmu Pengetahuan Alam (FMIPA) Tanggal 18 Oktober 2002 di Balai Pertemuan UPI Bandung. 
Rustaman, N.Y. (2012). Trend Penelitian Pendidikan: Kasus Penelitian Pendidikan Sains. Prosiding Seminar Nasional Pendidikan Pendidikan IPA Fakultas Keguruan dan Ilmu Pendidikan Universitas Pendidikan Indonesia, di Bandung, 2012.

Rustaman, N. Y. (TT). Pendidikan Biologi dan Trend Penelitiannya. Diunduh dari http://file.upi.edu/Direktori/SPS/PRODI.PENDIDIKAN_IPA/1950123119790 32-

NURYANI_RUSTAMAN/PENDIDIKAN_BIOLOGI_DAN_TREND_PENE LITIANNYAv.pdf pada Jumat, 23 September 2016 pukul 14.56 WIB.

Setyaningsih, D.A. (2007). Efektvitas Penerapan Pendekatan Jelajah Alam Sekitar (JAS) dengan Model Pembelajaran Kooperatif Jigsaw pada Submateri Vetebrata di SMP N 3 Ungaran.” Skripsi. Universitas Negeri Semarang.

Sudarisman, S. (2013). Analisis Kecenderungan Metode Penelitian Skripsi Mahasiswa di Program Studi Pendidikan Biologi UNS. Makalah tidak dipublikasikan.

Sugiyono. (2012). Metode Penelitian Kuantitatif, Kualitatif, dan R\&D. Bandung: Alfabeta.

Teacher Training Department. (2012). Low-Cost Experiments for Biology. Kingdom of Cambodia Nation - Religion - King.

UNESCO. (2006). Teaching and Learning Materials for Biology. University of Witwatersrand, Johannesburg.

UNESCO. (2009). Current Challenges in Basic Science Education. Perancis.

Widodo, A. (1997). Arah dan Kecenderungan Skripsi atau Tugas Akhir Mahasiswa Jurusan Pendidikan Biologi. FPMIPA IKIP Bandung.

Widodo, A. (2009). Gambaran Penelitian Pendidikan Biologi: Perkembangan Penelitian di Jurusan Pendidikan Biologi FPMIPA UPI. Asimilasi, 1(1), 54-61. 